\title{
Project to include Index Sheets in the Polish National Bibliography of Cartographic Materials
}

by LUCYNA SZANIAWSKÃ

\section{BIBLIOGRAPHICAL GUIDE. OFFICIAL INDEX OF PUBLICATIONS ISSUED IN POLAND}

The first post-war volume of the Bibliographical Guide was published in 1946. As an official index of monographic publications it gives a description of all the publications based on legal deposits received by the National Library of Poland [Biblioteka Narodowa]. Bibliographic descriptions are standardized in accordance with Standard PN-82/N-01152.01 Bibliographic Book Description, which has been in force in Poland since 1984 (Sadowska, 2001). The descriptions must also comply with the requirements of the 1986 publication Book Cataloging Rules (Lenartowicz, 1986). The rules laid down in both above-mentioned documents comply with the international regulations formulated by the International Federation of Library Associations (IFLA) and are commonly known as ISBD(M) which, for the purpose of creating descriptions for the Bibliographical Guide came into use as early as 1976.

The Bibliographical Guide, as a current national bibliography, is issued bi-weekly and records firstly publications issued in Poland whose publisher or co-publisher is a Polish company or a foreign one residing in Poland, irrespective of the language of the document. It also includes publications issued abroad by Polish institutions or their divisions, e.g. Polish embassies. Since 1986 the Bibliographical Guide has been published in hard copy as well as on CD-ROM. Since 1998 descriptions have been provided in USMARC format and subsequently MARC21.

The contents of the bibliographical descriptions included in the Bibliographical Guide are characterized in two ways: by subject entries corresponding to the entries contained in the Dictionary of the Subject Entries Language of the National Library (Keedzielska, 2001), as well as by the Universal Decimal Classification UDC (Bielicka, 1997) published for use of national bibliographies and in public libraries. The UDC is composed of a specific set of symbols and rules determining their use. It serves a special purpose of describing the features of the subject matter and the form of documents, and makes it possible to retrieve documents having certain features, based on the input characteristics. The UDC lexical system is composed of two kinds of symbols: main and auxiliary ones. They are represented by Arabic numerals from 0 through 9 , as well as gauges and connective signs. The Arabic numerals are then used to form symbols, according to the principle of hierarchic expansion and the decimal system. The list of elementary lexical units and the corresponding phrases existing in the natural language form a set of the UDC information language tables. The rules determining the way to form expanded and complex symbols as well as their arrangement control the information collection in the catalogue. Since January 1, 1992 all the national publishers of the UDC tables have been working under the auspices of the UDC Consortium in The Hague, The Netherlands, whose main task is to keep and update the dictionary, which in 1993 contained over 60 thousand symbols.

For the current national bibliography published as the Bibliographical Guide, the National Library successively updates the UDC system tables and publishes them in a publication entitled Dictionary of the Subject Entries Language of the National Library. The latest edition appeared in 2001. It was compiled in the form of a computer database in compliance with the Polish system called MAK. It consists of 5945 symbols and takes into account all the changes introduced by the UDC Consortium. Ideally, a subject entry ought to represent the contents of a document and the essential features of the subject. If the subject is too general and leaves out some vital aspects, a qualifier is added. If this turns out to be insufficient, a more detailed subject is introduced. A certain degree of generalization is necessary for practical reasons. A full presentation of the contents of a document as well as full explanation of its main subject is impossible. The structure of a subject entry and the way of finding it is characteristic of each information system, e.g., the National Library system employs a model contrasting two subjects by means of the conjunction "a", which is the equivalent of the English "versus": Russia vs. Poland, Frost vs. Plants. Also, adjectives describing ethnicity, nationality and others are added, e.g. Art, French; Periodicals, Hungarian. Complex terms may be expressed by means of lexical units forming multi-word subjects, such as Mining Industry, Administrative Partition. However, in case of cartographic materials, the most frequently used model is more complex, being the logical ratio of collections represented by particular compound entries. For instance, a map depicting rye culture in Łomża region will be given the following subject entries: 


\section{Lomza (wod. Podlaskle ; okregg) - rolnktwo - mapy,}

\section{[Lomza (volvodeshlp Podlaskle ; reglon) - agrkulture - maps]}

2. Żyto - uprawa - Polska - mapy.

[Rye - culture - Poland - mape]

Neither of the entries is fully adequate for the map, both generalize but in different aspects: Łomża region is generalized into Poland and rye culture into agriculture. Equally common are simpler entries repeated many times attached to one description of a cartographic material.

\section{Radziej6w (woj. kujawsko-pomorskie ; okreg) - mapy turystyczne, 2. Radzlejów (woj, kujawsko-pomorskle) - mapy,}

\section{Plotrkow Kujewskl (woj. kujawsko-pomorakle) - mapy, 4. Osleclny (wo]. kujawsko-pomorskle) - mapy,}

\section{BIBLIOGRAPHICAL GUIDE INSERT. BIBLIOGRAPHY OF ELECTRONIC RESOURCES}

In 2001, the National Library began publishing a new Bibliographical Guide Insert, the Bibliography of Electronic Resources. The insert is semi-yearly included in issues No. 27 and 50 of the Guide. It contains descriptions of documents received by the Library as legal deposits. So far, only documents considered "monographic items" have been registered. In the future, registering documents considered "serial items" is planned. Naturally, Bibliographic descriptions made from objects are elaborated in accordance with Standard PN-N-01152-13, Standard Bibliographic Description for Electronic Resources. For the most part, alphabetical order was used. The basis of arrangement is "main entry", or, in its absence, "title proper". Subject entries are developed in accordance with the Dictionary of Subject Entries Language of the National Library. For the description of these materials, a formal qualifier -[Electronic Resources] has been introduced. The main part is supplemented by 4 indexes: Personal Index, Index to Titles, Index to Publishers and Index to Subjects.

\section{BIBLIOGRAPHICAL GUIDE INSERT. BIBLIOGRAPHY OF CARTHOGRAPHIC MATERIALS}

From 2005 on, the issuing of Bibliographical Guide Insert 2005 No. 1, Bibliography of Cartographic Materials is planned. It is to be an independent publication whose originator is the National Library. The individual stages of work will be carried out by its specialized units. The Map Department [Zakład Zbiorów Kartograficznych] will produce bibliographic descriptions, the Division of Data Processing [Dział Przetwarzania Danych] will work on descriptions from the catalogue base, processing them into a print-ready form, the Publishing Office of the National Library [Wydawnictwo Biblioteki Narodowej] will print the volumes. Since a decision has been made to supplement the bibliography with index sheets, co-operation with Polish publishers of multi-sheet maps will be necessary.

The contents and structure of each cartographic document description will be generated in accordance with regulations and legal acts passed in Poland. It will be made possible thanks to the Dictionary of Subject Entries Language of the National Library as well as Polish Standard Bibliographic Description for Cartographic Materials PN-N-01152-5 (Polish Standard, $\underline{2001}$ ). The current national bibliography will register documents received by the National Library within the given period of time (six-monthly) as a legal deposit only. Since there are other publications of this kind, for example the ones describing books or related to music, as well as electronic documents on the Polish publishing market, some reference should be made to them for the subject matter and the format. Bearing in mind the specialist nature of the described objects as well as the lack of experience, however, it was decided that an interim volume would be issued and circulated in a limited number among the prospective users of the new bibliography. It is hoped that the feedback received will help to decide the final format. 


\section{COMPARISON OF BIBLIOGRAPHIES: GERMAN \& DANISH VERSUS THE NATIONAL LIBRARY OF POLAND PROPOSAL}

To start with, we have decided to base the bibliography on the experience of national bibliographies published in other countries of Europe. The most useful appeared to be the German bibliography published by professional teams employed in major German libraries entitled: Deutsche Nationalbibliographie und Bibliographie der im Ausland erschienenen deutschsprachigen Verõffentlchungen. Amtsblatt, C Karten, as well as the Danish bibliography completed by the Map Department of the Royal Library in Copenhagen Dansh Kortfortengnelse. Comparison of the two bibliographies enabled us to choose options that seem to be the most relevant and suitable in the case of the Polish current bibliography of cartographic materials (see table1).

\section{Table 1}

\begin{tabular}{|c|c|c|c|}
\hline Pubsher: & Cemen & Danith & Pollish \\
\hline Fraplancy & quartanty & yearity & semblyaty \\
\hline $\begin{array}{l}\text { The number of deschitions } \\
\text { ha viune: }\end{array}$ & 6.4., 386, 470, 687 & e.4. 150, 110 & 9.7 .700 .800 \\
\hline The number of text payed & $0.4 \cdot 47,55,72$ & $0,4,22,17$ & $\begin{array}{l}\text { e. } 80,90 \\
+8 \text { indtoxes }\end{array}$ \\
\hline 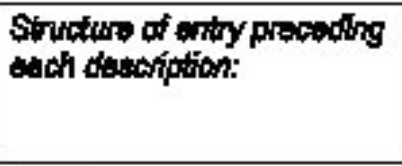 & $\begin{array}{l}1 \text { or } 2 \text { elementa: } \\
1 \text { - tile proper } \\
\text { 2- scels }\end{array}$ & $\begin{array}{l}\text { 3 elements: } \\
\text { 1-geographical name } \\
\text { 2-subject } \\
3 \text { - sogilo }\end{array}$ & $\begin{array}{l}\text { 2 elemonts: } \\
\text { 1-geographical namo } \\
\text { 2- gcale }\end{array}$ \\
\hline $\begin{array}{l}\text { Sigan, } \\
\text { priter: }\end{array}$ & $\begin{array}{l}\text { DaN, LSEN, } \\
\text { price }\end{array}$ & $\begin{array}{l}\text { IșN, } \\
\text { price }\end{array}$ & ISEN \\
\hline 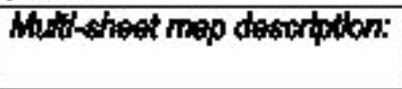 & $\begin{array}{l}\text { deacription of al tha gheats } \\
\text { numerleally arranged }\end{array}$ & 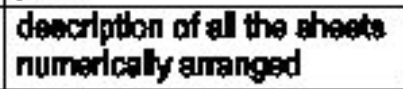 & $\begin{array}{l}\text { deacription of al the pheaks } \\
\text { numerically arranged }\end{array}$ \\
\hline introdueton to blyogrephy & $\begin{array}{l}\text { desortpton structure } \\
\text { In German }\end{array}$ & $\begin{array}{l}\text { description structure } \\
\text { In Darleh and Endles }\end{array}$ & $\begin{array}{l}\text { description gtructure } \\
\text { In Pollah and Enfllah }\end{array}$ \\
\hline Mntex sheots: & nons & $\begin{array}{l}1 \text { index of } 1 / 25,000 \\
\text { toposraphic maps }\end{array}$ & 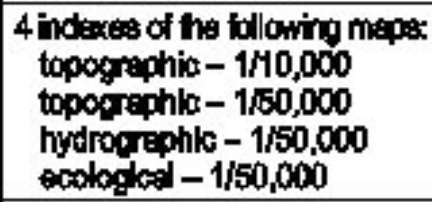 \\
\hline Reterentos: & $\begin{array}{l}\text { 1-pubithers } \\
\text { 2- ISENisBN } \\
\text { 3- ttes proper } \\
\text { + tiles paralel }\end{array}$ & none & $\begin{array}{l}\text { 1- corporato neme } \sigma \\
\text { personal name } \\
\text { 2- LBN } \\
\text { 3- thes proper + thlob paraled }\end{array}$ \\
\hline
\end{tabular}

The above table compares similarities and differences between the selected national bibliographies, thus making it possible to compare both their subject matter and the physical features. The number of cartographic publications in Poland has been on the increase in the last few years, and has reached about 1600 titles. Therefore, it has been decided that the bibliography would be issued six-monthly. In this case, each of the volumes would include about 800 titles of maps and atlases, at a level of detail similar to that in Danish publications. They would be supplemented by similar indexes as well as an introduction in Polish and English. The number of printed pages would vary between 80 and 90 . With the inclusion of the index sheets of the map series, Topographic Map of Poland 1:10,000, Topographic Map of Poland 1:50,000, Hydrographic Map of Poland 1:50,000 and Ecological Map of Poland 1:50,000, each occupying 2 adjoining pages (A3 format), the number of pages in each issue will not exceed 100.

\section{PUBLICATION ACTIVITIES OF MULTI-SHEET MAPS}

In recent years the Navy, Civil, Geological and Aviation Services have taken a decision to cease printing maps on paper. An example is the Detailed Geological Map of Poland 1:50,000, which has been produced by the Polish Geological Institute [Instytut Geologiczny], the largest producer of geological cartographic publications. It is the basic geological map of the country and since 1996 has been produced using of computer technology. By the end of 2002, 895 sheets out of 1025 covering the whole country were printed. Since then it has been made available in electronic form, therefore the National Library does not receive copies. This particular map as well as other electronically stored maps will for the time being not be included in the bibliography. The other multi-sheet maps are produced by two Polish institutions - the Head Office of Geodesy and 
Cartography [Główny Urząd Geodezji i Kartografii] and by the Military Geography Division of the General Staff of the Polish Armed Forces [Zarząd Geografii Wojskowej Sztabu Generalnego Wojska Polskiego]. The maps in question are official topographic and thematic maps. The Head Office of Geodesy and Cartography produce and publish two multi-sheet topographic map series at 1/10,000 and 1/50,000. In the recent years the maps have been produced as a joint activity between the national administration and local governments. Both these maps are produced in the international sheet division, on the 1992 system based on ellipsoid GRS-80, conforming to the original specification. As a rule, the producers are specialized regional geodesy - cartography enterprises and the largest of them work in Rzeszów, Cracow, Lublin, Wrocław, Olsztyn, Białystok and Elblag, and also the Polish Geodesy - Cartography Enterprise in Warsaw which has skilled personnel and modern production facilities. The privatised enterprises produce topographic maps under supervision of the Head Office of Geodesy and Cartography and the Regional Assembly Chairmen's Offices of individual memberships.

According to reports published by the Head Office of Geodesy and Cartography, the Topographic Map of Poland 1:10,000 map was initially produced on the "1942 system". Of the 16,155 sheets covering the Polish territory in this series, 338 sheets were printed; 1398 sheets were drawn up for printing in a two-color print in diapositive form. In the "1992 system", 3870 sheets were printed of the 17,264 covering the country. 3053 sheets of the 1/10,000 map were published till the end of 2002 . Coverage of the country's area amounted to $31 \%$, together with the sheets in the above mentioned " 1992 system". In the year 2003, 761 sheets were issued.

Country coverage of the Topographic Map of Poland 1:50,000 is at 55\%. A total of 591 sheets of the 1083 covering the country in the "1992 system" have been published, including 202 sheets published between 1999 and 2002. Since June 2002, as a result of a cooperation agreement between the Military Geography Division and the State Geodetic and Cartographic Service, the Head Office of Geodesy and Cartography has started producing a 1/50,000 map on the basis of Vector Smart Map Level 2 (VmapL2), taking the NATO standards into account. In 2003, 115 sheets of the map depicting the areas of the northeast and west of Poland were prepared. After the Second World War map the Military Geographical Institute [Wojskowy Instytut Geograficzny] resumed production, mainly for military purposes. In 1947 it was renamed the Topographic Survey of the Polish Armed Forces, but the maps it produced afterwards were treated as strictly confidential for several years. In the 1990's the maps were updated and re-edited in order to produce versions for civil purposes. Though new military topographic and general-topographic maps are not for sale, sets of them are available in cartographic collections of large scientific libraries, among others as a legal deposit of the National Library of Poland.

At present, the Military Geography Division is producing topographic and general-topographic maps at different scales. Map Series covering the whole territory of Poland and adapted to the NATO standards were produced using modern digital technologies (Sobczyński, 2000a). The principal elements of the adaptation process were the changing of the Krassowski reference ellipsoid and the "1942 reference systems" to the WGS84 system and also the change of the Gauss-Krüger projection to UTM (Universal Transverse Mercator) projection or Lambert projection. The Military Geography Division is currently focusing on updating methods and issuing maps on paper from digital products. An example of this is the launch of the production of the Topographic Map of Poland 1:50,000 (Sobczyński, 2000b).

There are two more thematic map series published on paper left to describe and their index sheets will be included in the current bibliography of cartographic materials. They are maps of Poland's natural environment issued by the Head Office of Geodesy and Cartography. One is the Ecological Map of Poland 1:50,000, depicting the state of the natural environment and the effects of mainly human-inspired changes occurring within it. They make allowances for the adjustment of Polish regulations to the European Union legislation, particularly in the field of environmental protection (Herdaś, 2001). The other series, the Hydrographical Map of Poland 1:50,000, describes the state and conditions of water systems in relation to the natural environment. This allows GIS-3 systems to be fed directly with thematic data. Both are published at the scale of $1 / 50,000$ and produced in both paper and digital versions. The digital versions consist of 70 layers, the objects on these layers being connected to an attribute database containing their quantitative and qualitative characteristics. According to the reports published by the Head Office of Geodesy and Cartography, by the end of 2003, 338 sheets of the hydrographic series (covering the west and the south-west of Poland) and 380 sheets of the ecological series (covering mainly the west and the south of Poland) were issued. The principal producers of both maps is GEOPOL, a company in Poznań working jointly with Cracow, Sosnowiec, Łódź and Wrocław university centres when compiling their contents and commentaries included with each sheet (Activity, 2004). 

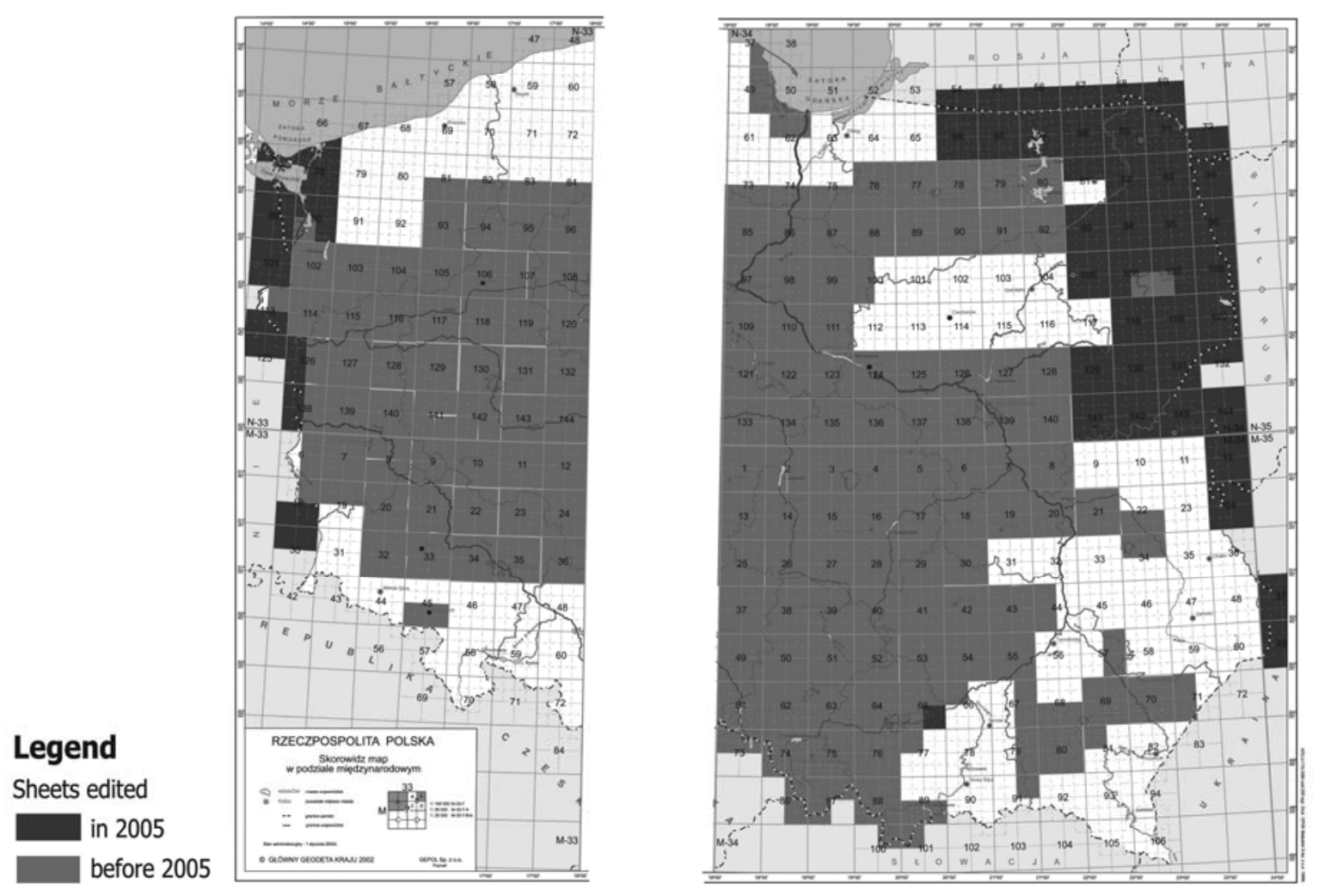

The index sheets for multi-sheet maps, which will be received by the Library on the strength of the inter-company cooperation, need to be re-edited so that their final format will be monochromes and can be A3 format. Another problem will be to maintain the link between the text and illustrative parts in each volume. Thus, the sheets described in the catalogue part should have their graphic representation on a corresponding index sheet. It is also difficult to predict the regularity of dispatch of publications by publishers. Up to now the situation has been far from ideal, since most of the maps have not reached the National Library until the end of the year.

\section{REFERENCES}

“Activity of the Geodesy and Geographical Information Systems Department in the field of cartographic works" [Działalność Departamentu Geodezji i Systemów Informacji Geograficznej GUGiK w zakresie prac kartograficznych]. Biuletyn Informacyjny Głównego Geodety Kraju, (2004)2, 10-11.

Bielicka, Lucyna, Adam Stopa andTeresa Turowska. Universal Decimal Classification UDC [Uniwersalna Klasyfikacja Dziesiętna. UDC - P022]. Warszawa : Biblioteka Narodowa, 1997. ISBN 83-70009-227-6.

Herdaś, Jacek: "Depicting Built-up Areas on Modern Polish Topographic Maps” [Przedstawienie zabudowy na współczesnych polskich mapach topograficznych]. Polish Cartographical Review [W: "Polski Przegląd Kartograficzny"], 33(2001)2, 127-136.

Kędzielska, Joanna, Wanda Klenczon and Anna Stolarczyk. Dictionary of the Subject Entries Language of the National Library [Słownik języka haseł przedmiotowych Biblioteki Narodowej]. Ed. 4. Warszawa : Biblioteka Narodowa, 2001. Vol.12. ISBN 83-7009-345-0.

Lenartowicz, Maria. Book Cataloging Rules. Volume 1. Bibliographical description [Przepisy katalogowania książek. Cz. 1. Opis bibliograficzny]. Ed. 2. Warszawa : Stowarzyszenie Bibliotekarzy Polskich, 1986. ISBN 83-0000-59-00.

Polish Standard Bibliographical Description for Cartographic Materials [Polska Norma. Opis bibliograficzny. Dokumenty kartograficzne. PN-N-01152-5]. Warszawa : Polski Komitet Normalizacyjny, 2001. ISBN 83-7340-452-X. 
Sadowska, Jadwiga. Bibliographical Institute of the National Library [Instytut Bibliograficzny Biblioteki Narodowej]. Biblioteka Narodowa, 2001. ISBN 83-7009-327-2.

Sobczyński, Eugeniusz, Zdzisław Tomaszewski and Janusz Sielecki. Polish Military Maps vs. the NATO standards [Polskie wojskowe mapy w standardach NATO (Przewodnik)]. Warszawa : Ministerstwo Obrony Narodowej. Sztab Generalny WP, 2000a.

Sobczyński, Eugeniusz and Janusz Sielecki: "Modern Military Maps of the Topographic Service of the Polish Armed Forces [Współczesne mapy wojskowe Służby Topograficznej WP]. In: Polish Cartography on the Threshold of the XXI century. [In: Kartografia polska u progu XXI wieku]. Warszawa : Główny Urząd Geodezji i Kartografii, 2000b, p.33-55. ISBN 83-2390706-4.

\section{WEB SITES REFERRED TO IN THE TEXT}

IFLA - International Federation of Library Associations. http://www.ifla.org/index.htm

National Library of Poland. http://www.bn.org.pl/

UDC Consortium - Universal Decimal Classification Consortium. http://www.udcc.org/ 